\title{
Thermodynamic and Experimental Study on Efficient Extraction of Valuable Metals from Polymetallic Nodules
}

\author{
Kun Su ${ }^{1}$, Xiaodong Ma ${ }^{1, * \mathbb{C}}$, John Parianos ${ }^{2}$ and Baojun Zhao ${ }^{1}$ \\ 1 School of Chemical Engineering, University of Queensland, St Lucia, Brisbane 4072, Australia; \\ k.su@uq.net.au (K.S.); baojun@uq.edu.au (B.Z.) \\ 2 Nautilus Minerals, East Brisbane, Brisbane 4169, Australia; jmp@nautilusminerals.com \\ * Correspondence: x.ma@uq.edu.au; Tel.: +61-733-653-508
}

Received: 27 February 2020; Accepted: 15 April 2020; Published: 17 April 2020 updates

\begin{abstract}
Polymetallic nodules are promising resources for the extraction of valuable metals such as copper, nickel, and cobalt, as well as manganese alloys. To achieve efficient extraction of useful metals from the emerging resource, high-temperature carbothermic reduction of nodules was investigated by optimizing the reductant addition, slag and alloy systems. Thermochemical software FactSage was used to predict the liquidus temperature of the slag system, which is not sensitive to $\mathrm{FeO}, \mathrm{CaO}$ and $\mathrm{Al}_{2} \mathrm{O}_{3}$, but decreases significantly with decreasing $\mathrm{MnO} / \mathrm{SiO}_{2}$ mass ratio. The experiments were designed to reduce the oxides of $\mathrm{Cu}, \mathrm{Co}$ and $\mathrm{Ni}$ completely, and reduce $\mathrm{FeO}_{\mathbf{x}}$ partially depending on the amount of graphite addition while leaving the residual slag for further processing into ferromanganese and/or silicomanganese alloys. $\mathrm{Co}, \mathrm{Cu}$ and $\mathrm{Ni}$ concentrations in the alloy decreased with increasing graphite addition. The optimal reduction condition was reached by adding $4 \mathrm{wt} \%$ graphite at the $\mathrm{MnO} / \mathrm{SiO}_{2}$ mass ratio of 1.6 in slag. The most effective metal-slag separation was achieved at $1350^{\circ} \mathrm{C}$, which enables the smelting reduction to be carried out in various furnaces.
\end{abstract}

Keywords: polymetallic nodules; carbothermic reduction; valuable metals; liquidus temperature

\section{Introduction}

The manganese and iron concretions on the sea bottom formed of concentric layers around a core are known as manganese nodules or polymetallic nodules. Polymetallic nodules contain many valuable elements such as $\mathrm{Cu}, \mathrm{Ni}$ and $\mathrm{Co}$, besides $\mathrm{Mn}$ and $\mathrm{Fe}$. Trace amounts of Mo, $\mathrm{V}$, and rare earth elements (REEs) are also present in the nodules. As the land-based resources for $\mathrm{Mn}, \mathrm{Cu}, \mathrm{Ni}$ and $\mathrm{Co}$ are depleting very fast, the exploration and exploitation of manganese nodules are essential to meet the future demands of $\mathrm{Cu}, \mathrm{Ni}, \mathrm{Co}$ and $\mathrm{Mn}$ in the world [1]. In recent years, the exploitation of manganese nodules from the deep sea has once again become a political and economic topic [2,3]. One of the biggest and economically most important areas, where polymetallic nodules can be found, is situated between the Clarion and Clipperton Zones in the tropical northern Pacific Ocean. The nodules could serve as an enormous reserve for these metals since they are found in relative abundance. The nodules in the Clarion Clipperton Zone alone constitute an estimated reserve of up to 220 million tons of copper, up to 260 million tons of nickel, up to 50 million tons of cobalt, and up to 5 billion tons of manganese [2,3]. These estimated amounts currently surpass universal land-based reserves in mines for $\mathrm{Ni}, \mathrm{Cu}, \mathrm{Co}$ and $\mathrm{Mn}$. Recently, the increased interest in electrical energy storage and rapid growth in the market for electric vehicles will make the polymetallic nodules promising resources to produce component metals of batteries.

Polymetallic nodules are composed of complex Mn-oxides and Fe-oxyhydroxide minerals with mineral particles smaller than one $\mu \mathrm{m}$. Ni, $\mathrm{Cu}, \mathrm{Co}$ and $\mathrm{Mo}$ are found in the manganese- or iron-oxide matrix [4]. Therefore, beneficiation with classic techniques (density separation, floatation, etc.) to 
generate a metal-bearing concentrate, which could be directly used in existing industries, is not effective [5]. Considerable research has focused on the extraction of valuable metals from ocean nodules. The nodule processing techniques are broadly divided into three categories: (1) hydrometallurgical processing (only); (2) pyrometallurgical treatment followed by hydrometallurgical processing; (3) hydrometallurgical processing followed by pyrometallurgical treatment for recovery of $\mathrm{Mn}$ from leaching residue [6-8]. Various hydrometallurgical approaches included reductive ammonia leaching [9-14], reduction and sulphuric acid leaching [15-18], reduction and hydrochloric acid leaching [19,20], and other integrated or synergistic solvent extractions [21-23]. Reductive ammonia and sulphuric acid leaching cannot recover manganese, which makes up nearly half of the nodules' value. Reductive hydrochloric acid leaching can recover manganese, however, the corrosive nature of chloride is the main disadvantage [24]. With time, the environmental regulations are becoming more and more stringent, it is mandatory to properly deal with the disposal of solid/liquid effluents generated during the hydrometallurgical processes. Some researchers reported the pyrometallurgical route to recover the $\mathrm{Cu}, \mathrm{Ni}, \mathrm{Co}$, as well as $\mathrm{Mn}$ metals from polymetallic nodules at temperatures above $1400{ }^{\circ} \mathrm{C}$ [25-30]. Recently, the pyrometallurgical process with "zero-waste" has been proposed [28,30], based on the "Inco-process" [7]. Valuable metals such as $\mathrm{Cu}, \mathrm{Co}$, Ni are recovered first by smelting reduction at high temperature or sulfurizing into matte. The slag generated contains high manganese can be used in the existing production plants for ferromanganese or silico-manganese alloys. Since the $(\mathrm{Cu}+\mathrm{Ni}+\mathrm{Co})$ grade of nodules is similar to nickel laterite, the pyrometallurgical treatment route of nickel laterites [31], which is a well-established industrial method, namely, the rotary kiln-electric arc furnace (RKEF) process, can be used to treat nodules to save a new capital investment to build a new process for nodules. However, limited experimental data on the extraction of valuable metals have been reported due to a limited supply of nodules. The operating parameters need to be optimized to prepare industrial scale-up. Of particular significance is that the melting temperatures of slags over $1500^{\circ} \mathrm{C}$ were typically quoted significantly higher, which results in high consumption of energy and refractory. Therefore, in this study, the pyrometallurgical process of extraction of useful minerals from deep-sea nodules will be developed and optimized to produce Fe-Cu-Co-Ni master alloys and Mn-rich slag.

\section{Materials and Methods}

\subsection{Nodule Materials}

The nodules employed in this study were dredged from the Clarion-Clipperton Zone of the Pacific Ocean. The chemical composition of the nodule sample is shown in Table 1.

Table 1. Chemical composition of the nodules ( $\mathrm{wt} \%$ ).

\begin{tabular}{cccccccccc}
\hline $\mathrm{MnO}$ & $\mathrm{SiO}_{2}$ & $\mathrm{Fe}_{2} \mathrm{O}_{3}$ & $\mathrm{Al}_{2} \mathrm{O}_{3}$ & $\mathrm{MgO}$ & $\mathrm{Na}_{2} \mathrm{O}$ & $\mathrm{CaO}$ & $\mathrm{NiO}$ & $\mathrm{CuO}$ & $\mathrm{CoO}$ \\
\hline 40.25 & 13.48 & 8.28 & 4.67 & 3.48 & 3.01 & 2.16 & 1.71 & 1.65 & 0.30 \\
\hline $\mathrm{K}_{2} \mathrm{O}$ & $\mathrm{TiO}_{2}$ & $\mathbf{P}_{2} \mathrm{O}_{5}$ & $\mathrm{BaO}$ & $\mathrm{ZnO}$ & $\mathrm{SO}_{3}$ & $\mathbf{P b O}$ & $\mathrm{Cr}_{2} \mathrm{O}_{3}$ & $\mathrm{LOI}$ & $\mathrm{MnO}_{\mathbf{S i O}}$ \\
\hline 1.24 & 0.52 & 0.32 & 0.22 & 0.20 & 0.17 & 0.03 & 0.01 & 17.28 & 3.0 \\
\hline
\end{tabular}

The microstructure and elemental mapping of a local area of an example nodule were determined by scanning electron microscopy (SEM) with energy dispersive X-ray spectrometry (EDS), which is shown in Figure 1. The nodule consists of concentrically banded zones of micro-layers around a nucleus. The microstructure of the shell is dense, while it is looser in the core of the nodule scanned. The maps of the distribution of each element across the local area show the distribution of $\mathrm{Mn}$ and $\mathrm{Fe}$ is in striation. $\mathrm{Si}$ is incorporated with $\mathrm{Al}, \mathrm{Na}, \mathrm{K}$ and $\mathrm{Ca}$ as impurity minerals, likely detrital deep-sea ooze [1]. Valuable metal elements such as $\mathrm{Cu}, \mathrm{Co}$ and $\mathrm{Ni}$ in low concentrations are uniformly distributed in the nodule matrix. Ba is found to be associated with $\mathrm{S}$, which is most likely considered to be precipitated barite $\left(\mathrm{BaSO}_{4}\right)$. 


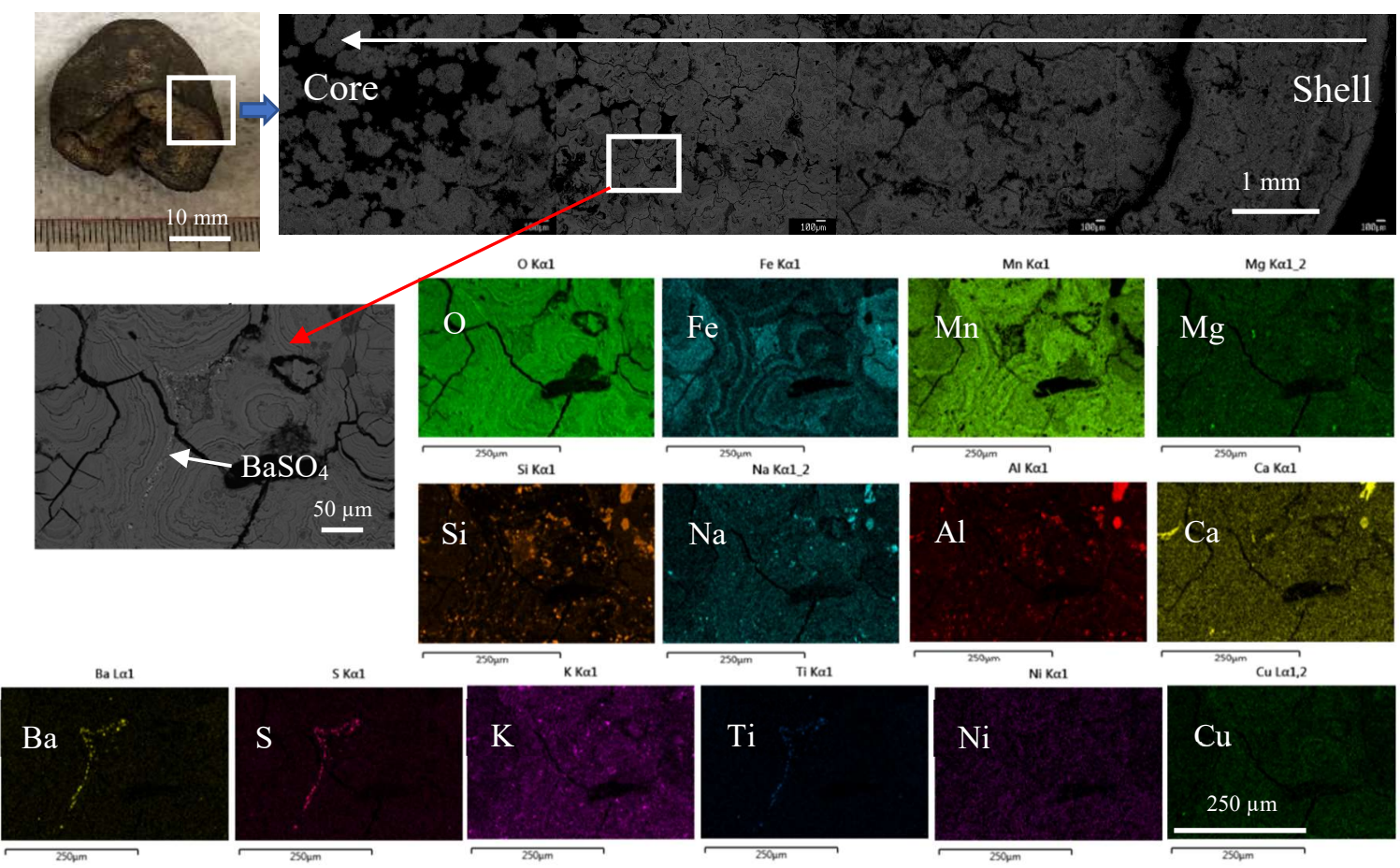

Figure 1. Microstructure and element distribution measured by SEM-EDS.

\subsection{Thermodynamic Consideration}

\subsubsection{Effect of Flux on the Liquidus Temperature of Resulted Slags}

Thermodynamically, it is possible to reduce the oxides of nickel, copper, cobalt, and iron to metals while leaving the manganese oxide over a wide range of temperatures. The selective reduction of $\mathrm{NiO}$, $\mathrm{CuO}, \mathrm{CoO}$ and $\mathrm{Fe}_{2} \mathrm{O}_{3}$ over $\mathrm{MnO}$ by carbon reductant can be simplified in Reactions (1)-(4) with a ratio of $\mathrm{CO}$ and $\mathrm{CO}_{2}$ gases between critical limits. The iron oxide can be fully or partially reduced in the smelting process to adjust the slag composition and to control the alloy grade. For the sake of convenience, the stoichiometric amount of carbon needed to reduce the oxides is $2.4 \mathrm{~g}$ per $100 \mathrm{~g}$ ore, assuming only $\mathrm{CO}$ is generated during carbon gasification instead of a mixer of $\mathrm{CO} / \mathrm{CO}_{2}$.

$$
\begin{gathered}
\mathrm{NiO}+\mathrm{C} \rightarrow \mathrm{Ni}+\mathrm{CO} / \mathrm{CO}_{2}, \\
\mathrm{CuO}+\mathrm{C} \rightarrow \mathrm{Cu}+\mathrm{CO} / \mathrm{CO}_{2}, \\
\mathrm{CoO}+\mathrm{C} \rightarrow \mathrm{Co}+\mathrm{CO} / \mathrm{CO}_{2}, \\
\mathrm{Fe}_{2} \mathrm{O}_{3}+\mathrm{C} \rightarrow \mathrm{FeO} / \mathrm{Fe}+\mathrm{CO} / \mathrm{CO}_{2} .
\end{gathered}
$$

In similar commercial scaled operations, some common oxides such as $\mathrm{CaO}, \mathrm{SiO}_{2}$, and $\mathrm{Al}_{2} \mathrm{O}_{3}$ are normally added as a flux to adjust the slag composition and keep the smelting slag in a fully molten state at a suitable temperature. The thermodynamic software package FactSage 7.2 [32] with the suitable optimized compounds and solution databases was used to predict the liquidus temperatures of the $\mathrm{MnO}-\mathrm{SiO}_{2}-{ }^{\prime \prime} \mathrm{FeO}$ " $-\mathrm{Al}_{2} \mathrm{O}_{3}-\mathrm{MgO}-\mathrm{Na}_{2} \mathrm{O}-\mathrm{CaO}-\mathrm{K}_{2} \mathrm{O}$ system at iron saturation condition based on the normalization of major components of Table 1 and assumption of full reduction of $\mathrm{NiO}, \mathrm{CuO}$ and $\mathrm{CoO}$. The composition of the slag used for the FactSage calculation is given in Table 2.

The FactSage databases including FactPS (for pure compounds), FToxide (for solid and liquid oxide solutions), and FTmisc (for liquid alloys), were used. The effects of the $\mathrm{MnO} / \mathrm{SiO}_{2}$ ratio and $\mathrm{CaO}$, $\mathrm{Al}_{2} \mathrm{O}_{3}$, and " $\mathrm{FeO}$ " on the liquidus temperatures of the slag are shown in Figure 2. It can be seen from Figure $2 \mathrm{a}$ that the liquidus temperature increases with increasing $\mathrm{CaO}$ concentration in the monoxide 
primary phase field at different $\mathrm{MnO} / \mathrm{SiO}_{2}$ ratios but decreases in the olivine primary phase field at the $\mathrm{MnO} / \mathrm{SiO}_{2}$ ratio of 1.0. Figure $2 \mathrm{~b}$ shows the $\mathrm{Al}_{2} \mathrm{O}_{3}$ concentration has a little effect on the liquidus temperature at the $\mathrm{MnO} / \mathrm{SiO}_{2}$ ratio of 3.0. The liquidus temperature increases slightly with increasing $\mathrm{Al}_{2} \mathrm{O}_{3}$ concentration at the $\mathrm{MnO} / \mathrm{SiO}_{2}$ ratio of 2.0 in the monoxide primary phase field but decreases slightly at the $\mathrm{MnO} / \mathrm{SiO}_{2}$ ratio of 1.0 in the olivine primary phase field. It shows in Figure $2 \mathrm{c}$ that the $\mathrm{FeO}$ concentration has little effect on the liquidus temperature at different $\mathrm{MnO} / \mathrm{SiO}_{2}$ ratios, which indicates the liquidus temperature of slag will not change significantly when $\mathrm{FeO}$ in slag is partially or fully reduced.

It is clear from Figure 2 that the $\mathrm{MnO} / \mathrm{SiO}_{2}$ ratio has a significant impact on the primary phase field and liquidus temperature. $\mathrm{SiO}_{2}$ can be added as a flux to control the liquidus temperature of the slag. The effect of $\mathrm{SiO}_{2}$ or $\mathrm{MnO} / \mathrm{SiO}_{2}$ on the liquidus temperature is shown in Figure 3. It can be seen that the autogenic residue without $\mathrm{SiO} 2$ flux has a liquidus temperature of around $1570{ }^{\circ} \mathrm{C}$, which requires an operation temperature of above $1600^{\circ} \mathrm{C}$ to keep the slag fully liquid. By adding $\mathrm{SiO}_{2}$ flux, the primary phase field changes from mono-oxide to olivine $2(\mathrm{Ca}, \mathrm{Mn}) \mathrm{O} \cdot \mathrm{SiO}_{2}$ and rhodonite $(\mathrm{Ca}$, $\mathrm{Mn}) \mathrm{O} \cdot \mathrm{SiO}_{2}$. A large operating window with the liquidus temperature below $1300^{\circ} \mathrm{C}$ can be obtained with 10 to $50 \mathrm{wt} \% \mathrm{SiO}_{2}$ addition.
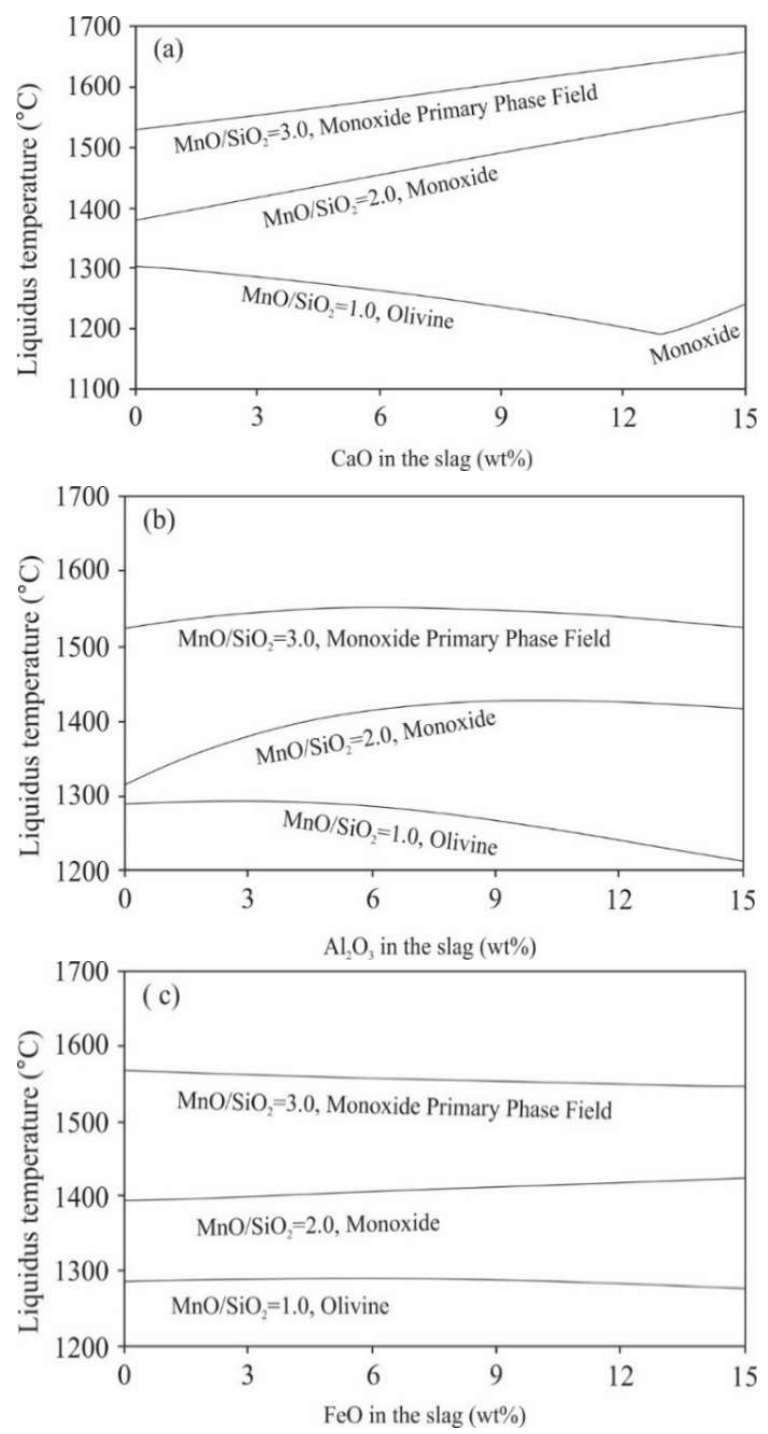

Figure 2. Effects of $\mathrm{CaO}, \mathrm{Al}_{2} \mathrm{O}_{3}$, and " $\mathrm{FeO}$ " on liquidus temperatures at different $\mathrm{MnO} / \mathrm{SiO}_{2}$ ratios in equilibrium with iron calculated with FactSage 7.2, (a) $\mathrm{CaO}$ in the slag,(b) $\mathrm{Al}_{2} \mathrm{O}_{3}$ in the slag,(c) $\mathrm{FeO}$ in the slag. 


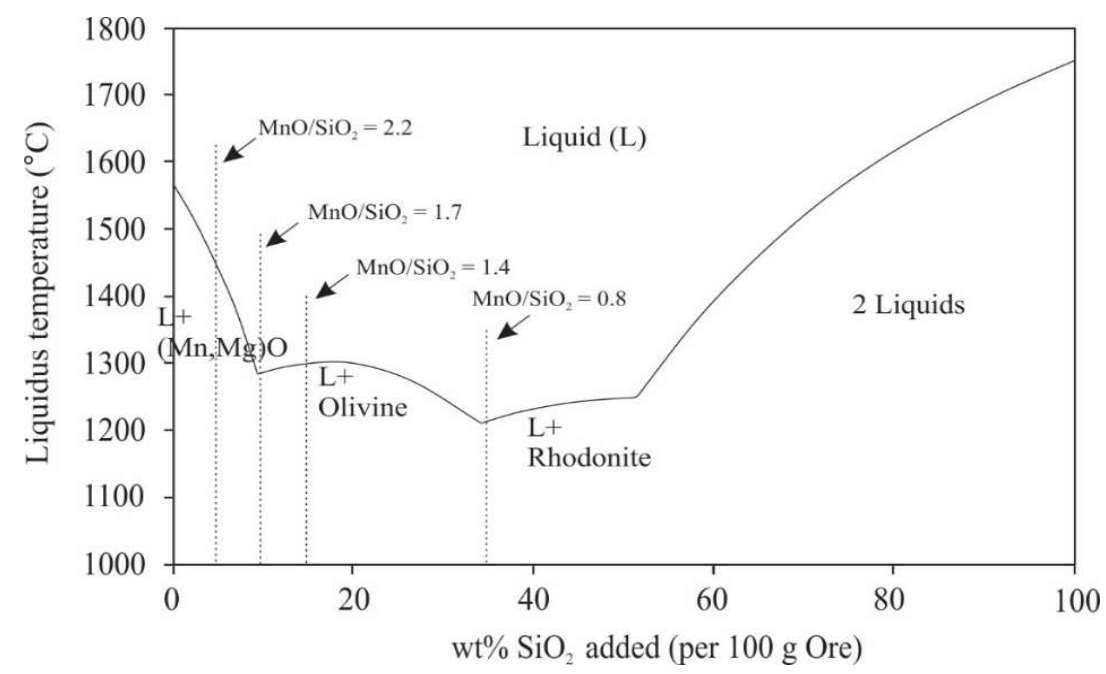

Figure 3. The effect of weight percent of $\mathrm{SiO}_{2}$ per $100 \mathrm{~g}$ nodules added as a flux on the liquidus temperature at a fixed ratio of other components.

Table 2. The composition of the slag used for FactSage calculation (wt $\%)$.

\begin{tabular}{|c|c|c|c|c|c|c|}
\hline $\mathrm{CaO}$ & $\mathrm{MnO} / \mathrm{SiO}_{2}$ & "FeO" & $\mathrm{Al}_{2} \mathrm{O}_{3}$ & $\mathrm{MgO}$ & $\mathrm{Na}_{2} \mathrm{O}$ & $\mathrm{K}_{2} \mathrm{O}$ \\
\hline $0-15$ & 1.0 & 9.6 & 6.2 & 4.6 & 4.0 & 1.6 \\
\hline $\mathrm{CaO}$ & $\mathrm{MnO} / \mathrm{SiO}_{2}$ & "FeO" & $\mathrm{Al}_{2} \mathrm{O}_{3}$ & $\mathrm{MgO}$ & $\mathrm{Na}_{2} \mathrm{O}$ & $\mathrm{K}_{2} \mathrm{O}$ \\
\hline $0-15$ & 2.0 & 9.6 & 6.2 & 4.6 & 4.0 & 1.6 \\
\hline $\mathrm{CaO}$ & $\mathrm{MnO} / \mathrm{SiO}_{2}$ & "FeO" & $\mathrm{Al}_{2} \mathrm{O}_{3}$ & $\mathrm{MgO}$ & $\mathrm{Na}_{2} \mathrm{O}$ & $\mathrm{K}_{2} \mathrm{O}$ \\
\hline $0-15$ & 3.0 & 9.6 & 6.2 & 4.6 & 4.0 & 1.6 \\
\hline $\mathrm{Al}_{2} \mathrm{O}_{3}$ & $\mathrm{MnO} / \mathrm{SiO}_{2}$ & "FeO" & $\mathrm{CaO}$ & $\mathrm{MgO}$ & $\mathrm{Na}_{2} \mathrm{O}$ & $\mathrm{K}_{2} \mathrm{O}$ \\
\hline $0-15$ & 1.0 & 9.6 & 2.9 & 4.6 & 4.0 & 1.6 \\
\hline $\mathrm{Al}_{2} \mathrm{O}_{3}$ & $\mathrm{MnO} / \mathrm{SiO}_{2}$ & "FeO" & $\mathrm{CaO}$ & $\mathrm{MgO}$ & $\mathrm{Na}_{2} \mathrm{O}$ & $\mathrm{K}_{2} \mathrm{O}$ \\
\hline $0-15$ & 2.0 & 9.6 & 2.9 & 4.6 & 4.0 & 1.6 \\
\hline $\mathrm{Al}_{2} \mathrm{O}_{3}$ & $\mathrm{MnO} / \mathrm{SiO}_{2}$ & “FeO" & $\mathrm{CaO}$ & $\mathrm{MgO}$ & $\mathrm{Na}_{2} \mathrm{O}$ & $\mathrm{K}_{2} \mathrm{O}$ \\
\hline $0-15$ & 3.0 & 9.6 & 2.9 & 4.6 & 4.0 & 1.6 \\
\hline “FeO” & $\mathrm{MnO} / \mathrm{SiO}_{2}$ & $\mathrm{Al}_{2} \mathrm{O}_{3}$ & $\mathrm{CaO}$ & $\mathrm{MgO}$ & $\mathrm{Na}_{2} \mathrm{O}$ & $\mathrm{K}_{2} \mathrm{O}$ \\
\hline $0-15$ & 1.0 & 6.2 & 2.9 & 4.6 & 4.0 & 1.6 \\
\hline “FeO" & $\mathrm{MnO} / \mathrm{SiO}_{2}$ & $\mathrm{Al}_{2} \mathrm{O}_{3}$ & $\mathrm{CaO}$ & $\mathrm{MgO}$ & $\mathrm{Na}_{2} \mathrm{O}$ & $\mathrm{K}_{2} \mathrm{O}$ \\
\hline $0-15$ & 2.0 & 6.2 & 2.9 & 4.6 & 4.0 & 1.6 \\
\hline “FeO” & $\mathrm{MnO} / \mathrm{SiO}_{2}$ & $\mathrm{Al}_{2} \mathrm{O}_{3}$ & $\mathrm{CaO}$ & $\mathrm{MgO}$ & $\mathrm{Na}_{2} \mathrm{O}$ & $\mathrm{K}_{2} \mathrm{O}$ \\
\hline $0-15$ & 3.0 & 6.2 & 2.9 & 4.6 & 4.0 & 1.6 \\
\hline
\end{tabular}

\subsubsection{Effect of Carbon Addition on the Reduction Degree}

The effect of carbon addition on the extension of the reduction was examined by FactSage 7.2 with the $\mathrm{SiO}_{2}$ addition of $10 \mathrm{wt} \%$ of ore weight at $1350{ }^{\circ} \mathrm{C}$. The recovery rate and alloy composition as a function of carbon addition are shown in Figure 4. It can be seen from Figure 4 that the $\mathrm{NiO}$ and $\mathrm{CuO}$ are first reduced and $\mathrm{Ni}$ and $\mathrm{Cu}$ concentrations in the alloy reached a maximum. With increasing carbon addition, $\mathrm{FeO}_{x}$ and $\mathrm{CoO}$ are reduced and their concentrations in the alloy gradually increase. At $1.2 \mathrm{wt} \%$ carbon addition, all $\mathrm{NiO}, \mathrm{CuO}$ and $\mathrm{CoO}$ are reduced and the alloy composition is $50 \mathrm{Ni}-12 \mathrm{Cu}-6 \mathrm{Co}-32 \mathrm{Fe}$. Further addition of carbon will continuously reduce $\mathrm{FeO}_{x}$ and increase $\mathrm{Fe}$ in the alloy. Accordingly, the concentrations of $\mathrm{Ni}, \mathrm{Co}$ and $\mathrm{Cu}$ will decrease as the total alloy increases. At carbon $2.5 \mathrm{wt} \%$, all 
$\mathrm{FeO}_{x}$ is reduced and $\mathrm{Fe}$ in the alloy reaches maximum. MnO starts to be reduced and carbon starts to dissolve into the alloy. Further addition of carbon will increase $\mathrm{Mn}$ and carbon concentrations in the alloy, and decrease the concentrations of other components in the alloy. Over $6.5 \mathrm{wt} \%$ carbon addition, the alloy composition will be constant, which is considered as the critical amount of graphite. Thus, adding graphite greater than $6.5 \mathrm{wt} \%$ would not change the composition of alloy significantly.

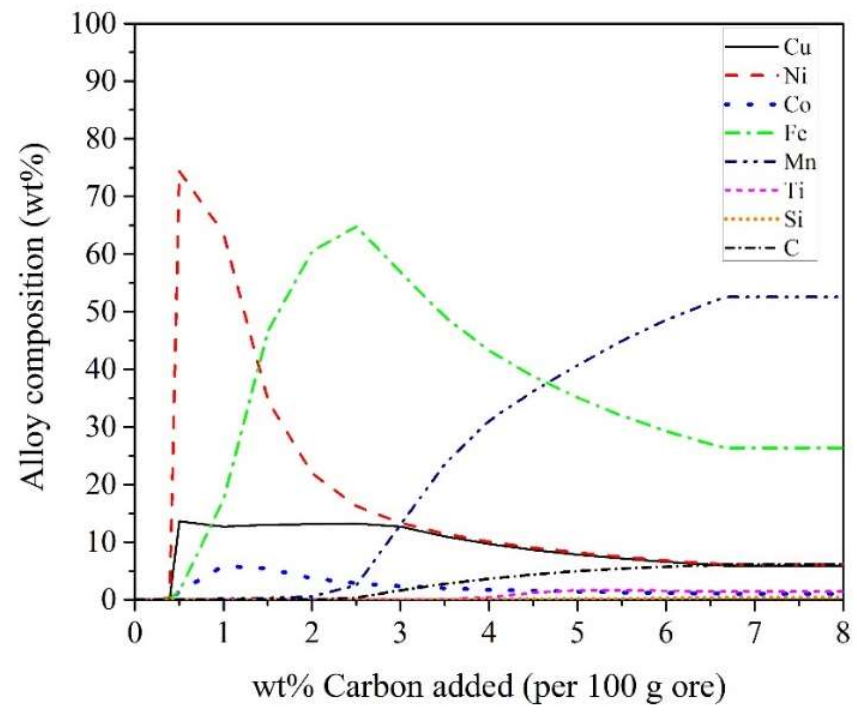

Figure 4. Reduction degree and alloy composition as a function of carbon addition for $100 \mathrm{~g}$ ore and $10 \mathrm{~g} \mathrm{SiO}_{2}$ at $1350{ }^{\circ} \mathrm{C}$.

\subsection{Experimental Procedure}

A vertical tube furnace with lanthanum chromate heating elements was used for the experiments. For each experimental run, $10 \mathrm{~g}$ of nodules were crushed into powder, and well mixed with flux and reductant in an agate mortar then pressed into briquette. Pure graphite powder (99.99 wt\%) was used as the reductant. The flux $\mathrm{SiO}_{2}$ and reductant graphite were added as per ore weight. The addition of $\mathrm{SiO}_{2}$ was adjusted based on the $\mathrm{MnO} / \mathrm{SiO}_{2}$ ratios and the liquidus temperatures showing in Figure 3 . The experimental conditions are shown in Table 3. The pelletized sample was then placed into an alumina crucible (ID: $18 \mathrm{~mm}, \mathrm{H}: 25 \mathrm{~mm}$ ). The sample was heated and pre-reduced under an Ar atmosphere at $1000{ }^{\circ} \mathrm{C}$ for $60 \mathrm{~min}$. Then, each pre-reduced sample was heated immediately to the smelting temperature and held there for $60 \mathrm{~min}$. A Pt-30\% Rh/Pt-6\% Rh thermocouple placed in an alumina sheath was located adjacent to the sample to monitor the temperature. The temperature was controlled to an accuracy of $\pm 2 \mathrm{~K}$. The samples were directly quenched into the water after the smelting reduction. After drying, they were mounted in resin and polished for metallographic analysis. The microstructures were examined by scanning electron microscopy coupled with X-ray energy-dispersive spectroscopy analysis (SEM-EDS). Compositions of the liquid and solid phases were measured by electron probe X-ray microanalysis (EPMA). The EPMA operation was conducted at an accelerating voltage of $15 \mathrm{kV}$ and a probe current of $15 \mathrm{nA}$. The standards used for analysis were spinel $\left(\mathrm{MgAl}_{2} \mathrm{O}_{4}\right)$ for $\mathrm{Al}$ and $\mathrm{Mg}$, wollastonite $\left(\mathrm{CaSiO}_{3}\right)$ for $\mathrm{Ca}$ and $\mathrm{Si}$, chalcopyrite $(\mathrm{FeCuS}) \mathrm{for} \mathrm{Cu}$, rutile $\left(\mathrm{TiO}_{2}\right)$ for $\mathrm{Ti}$, chromite $\left(\mathrm{FeCrO}_{4}\right)$ for $\mathrm{Cr}$, albite $\left(\mathrm{NaAlSi}_{3} \mathrm{O}_{8}\right)$ for $\mathrm{Na}$, orthoclase $\left(\mathrm{KAlSi}_{3} \mathrm{O}_{8}\right)$ for $\mathrm{K}_{\text {, }}$ olivine $\left(\mathrm{Ni}_{2} \mathrm{SiO}_{4}\right)$ for $\mathrm{Ni}$, spessartine $\left(\mathrm{Mn}_{3} \mathrm{Al}_{2} \mathrm{Si}_{3} \mathrm{O}_{12}\right)$ for $\mathrm{Mn}$, hematite $\left(\mathrm{Fe}_{2} \mathrm{O}_{3}\right)$ for $\mathrm{Fe}$, and pure Co for Co. The ZAF correction procedure, which is a series of multiplicative factors that account for the effects of atomic number (Z-stopping power, back-scattering factor and X-ray production power), absorption (A) and fluorescence (F), built-in the electron-probe software was applied automatically to the matrix correction. The average accuracy of the EPMA measurements is within $\pm 1 \mathrm{wt} \%$. The alloy droplets were collected to be measured by Inductively Coupled Plasma Optical Emission Spectrometer (ICP-OES). 
Table 3. Experimental conditions for nodule reduction.

\begin{tabular}{|c|c|c|c|c|c|c|c|c|}
\hline \multirow{2}{*}{$\begin{array}{l}\text { Exp. } \\
\text { No. }\end{array}$} & \multirow{2}{*}{$\begin{array}{l}\text { Nodules } \\
\text { (G) }\end{array}$} & \multirow{2}{*}{$\begin{array}{l}\text { Flux } \\
\mathrm{SiO}_{2}\end{array}$} & \multirow{2}{*}{$\frac{\text { Reductant }}{\text { Graphite }}$} & \multirow{2}{*}{ Crucible } & \multicolumn{2}{|c|}{ Pre-Reduction } & \multicolumn{2}{|c|}{ Reduction Smelting } \\
\hline & & & & & Temp. $\left({ }^{\circ} \mathrm{C}\right)$ & Time (Min) & Temp. $\left({ }^{\circ} \mathrm{C}\right)$ & Time (Min) \\
\hline ND1 & 10 & $9 \%$ & $0.8 \%$ & $\mathrm{Al}_{2} \mathrm{O}_{3}$ & 1000 & 60 & 1420 & 60 \\
\hline ND2 & 10 & $9 \%$ & $1.2 \%$ & $\mathrm{Al}_{2} \mathrm{O}_{3}$ & 1000 & 60 & 1420 & 60 \\
\hline ND3 & 10 & $9 \%$ & $12 \%$ & $\mathrm{Al}_{2} \mathrm{O}_{3}$ & 1000 & 60 & 1420 & 60 \\
\hline ND4 & 10 & $17.5 \%$ & $4 \%$ & $\mathrm{Al}_{2} \mathrm{O}_{3}$ & 1000 & 60 & 1350 & 60 \\
\hline ND5 & 10 & $17.5 \%$ & $8 \%$ & $\mathrm{Al}_{2} \mathrm{O}_{3}$ & 1000 & 60 & 1350 & 60 \\
\hline ND6 & 10 & $35 \%$ & $4 \%$ & $\mathrm{Al}_{2} \mathrm{O}_{3}$ & 1000 & 60 & 1300 & 60 \\
\hline ND7 & 10 & $35 \%$ & $8 \%$ & $\mathrm{Al}_{2} \mathrm{O}_{3}$ & 1000 & 60 & 1300 & 60 \\
\hline ND8 & 10 & $15 \%$ & $2 \%$ & $\mathrm{Al}_{2} \mathrm{O}_{3}$ & 1000 & 60 & 1350 & 60 \\
\hline ND9 & 10 & $15 \%$ & $4 \%$ & $\mathrm{Al}_{2} \mathrm{O}_{3}$ & 1000 & 60 & 1350 & 60 \\
\hline ND10 & 10 & $15 \%$ & $6 \%$ & $\mathrm{Al}_{2} \mathrm{O}_{3}$ & 1000 & 60 & 1350 & 60 \\
\hline ND11 & 10 & $15 \%$ & $8 \%$ & $\mathrm{Al}_{2} \mathrm{O}_{3}$ & 1000 & 60 & 1350 & 60 \\
\hline ND12 & 10 & $10 \%$ & $4 \%$ & $\mathrm{Al}_{2} \mathrm{O}_{3}$ & 1000 & 60 & 1350 & 60 \\
\hline ND13 & 10 & $5 \%$ & $4 \%$ & $\mathrm{Al}_{2} \mathrm{O}_{3}$ & 1000 & 60 & 1350 & 60 \\
\hline
\end{tabular}

Note: Exp., experienmnet; Temp., temperature.

\section{Results and Discussion}

\subsection{Pre-Reduction}

Pre-reduction was conducted to calcinate nodules and enable nickel, copper, cobalt and iron oxides to be partly reduced. The microstructures of samples ND2 and ND9 after pre-reduction at $1000{ }^{\circ} \mathrm{C}$ for $60 \mathrm{~min}$ are shown in Figure 5. In Figure 5a, the sample ND2 contains pyroxene $\left((\mathrm{Si}, \mathrm{Ti}, \mathrm{Mn}) \mathrm{O}_{2} \cdot(\mathrm{Al}, \mathrm{Fe})_{2} \mathrm{O}_{3} \cdot(\mathrm{Mn}, \mathrm{Fe}, \mathrm{Mg}, \mathrm{Ca}, \mathrm{Ni}) \mathrm{O}\right)$, rhodonite $\left((\mathrm{Mn}, \mathrm{Ca}, \mathrm{Mg}) \mathrm{O} \cdot \mathrm{SiO}_{2}\right)$, spinel $((\mathrm{Al}$, $\left.\mathrm{Fe})_{2} \mathrm{O}_{3} \cdot(\mathrm{Mn}, \mathrm{Fe}, \mathrm{Mg}, \mathrm{Ca}, \mathrm{Ni}) \mathrm{O}\right)$,), olivine $2(\mathrm{Mn}, \mathrm{Mg}, \mathrm{Ca}, \mathrm{Ni}, \mathrm{Fe}) \mathrm{O} \cdot \mathrm{SiO}_{2}$, and glass phases. At $1000{ }^{\circ} \mathrm{C}$, the mineral $\mathrm{SiO}_{2}-\mathrm{Al}_{2} \mathrm{O}_{3}$ incorporated with low melting point oxides $\mathrm{K}_{2} \mathrm{O}$ and $\mathrm{Na}_{2} \mathrm{O}$ may diffuse and react with $\mathrm{MnO}-\mathrm{FeO}$ phases. Some reactions occurred in the local area near the pore, where olivine and liquid together with rhodonite were formed. Metals were not observed in the samples after pre-reduction due to the insufficient reductant addition. In Figure $5 b$, alloy droplets were observed by the reduction with more reductant addition. Olivine and liquid phases were formed in the sample ND9. The alloy and liquid compositions are $38.4 \mathrm{Ni}-36.1 \mathrm{Fe}-19.7 \mathrm{Cu}-3.4 \mathrm{Co}-2.3 \mathrm{Mn}$ and $49.7 \mathrm{SiO}_{2}-13.4 \mathrm{MnO}-11.8 \mathrm{Al}_{2} \mathrm{O}_{3}-12.9 \mathrm{Na}_{2} \mathrm{O}-5.5 \mathrm{~K}_{2} \mathrm{O}-2.5 \mathrm{FeO}-2.8 \mathrm{CaO}-0.7 \mathrm{MgO}-0.6 \mathrm{TiO}_{2}$, respectively.

\subsection{Reduction Smelting}

\subsubsection{Effect of Reductant Addition on the Alloys and Slags}

The smelting process was conducted at high temperatures to further reduce nickel, copper, cobalt, and iron oxides to form the required alloys and slags. Figure 6 shows the pictures and microstructures of samples ND8, ND9, and ND10 after smelting at $1350{ }^{\circ} \mathrm{C}$ with a carbon addition of 2, 4, and $6 \mathrm{wt} \%$, respectively. It can be seen from Figure 6 a that in sample ND8, the slag contains spinel crystals and the alloy is not observed. In samples ND9 and ND10, the slag is fully liquid and alloy sphere (around $5 \mathrm{~mm}$ in diameter) settled at the bottom of the crucible can be easily separated from the slag, and small alloy droplets are also present in the slag. A small amount of graphite was left after smelting reduction in sample ND10, which indicates the addition of graphite was in excess. Comparing Figure 6a-c, when the addition of the reductant was insufficient, the liquidus temperature of slag was much higher due to the presence of $\mathrm{Fe}^{3+}$. Consider the results that no alloy was observed with $2 \mathrm{wt} \%$ graphite addition and excess graphite was observed with $6 \mathrm{wt} \%$ graphite addition. Therefore, an optimal addition of graphite is around $4 \mathrm{wt} \%$ per residues in terms of alloy morphology and full-liquid slag. The effect of the addition of graphite on the reduction extent of copper, nickel, cobalt, iron and manganese oxides will be discussed in the following section. 

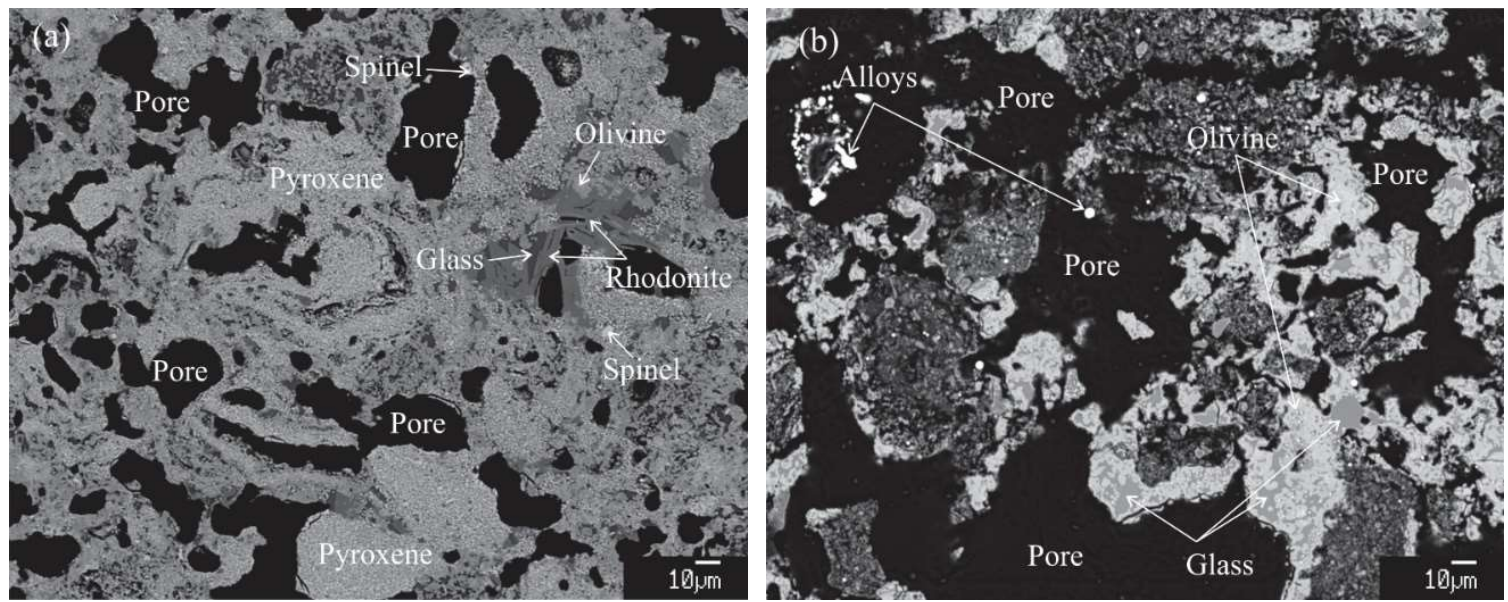

Figure 5. Microstructure of reduction sample after pre-reduction at $100{ }^{\circ} \mathrm{C}$ for $60 \mathrm{~min}$ : (a) sample ND2 with $1.2 \%$ graphite addition; (b) sample ND9 with $4 \%$ graphite addition.
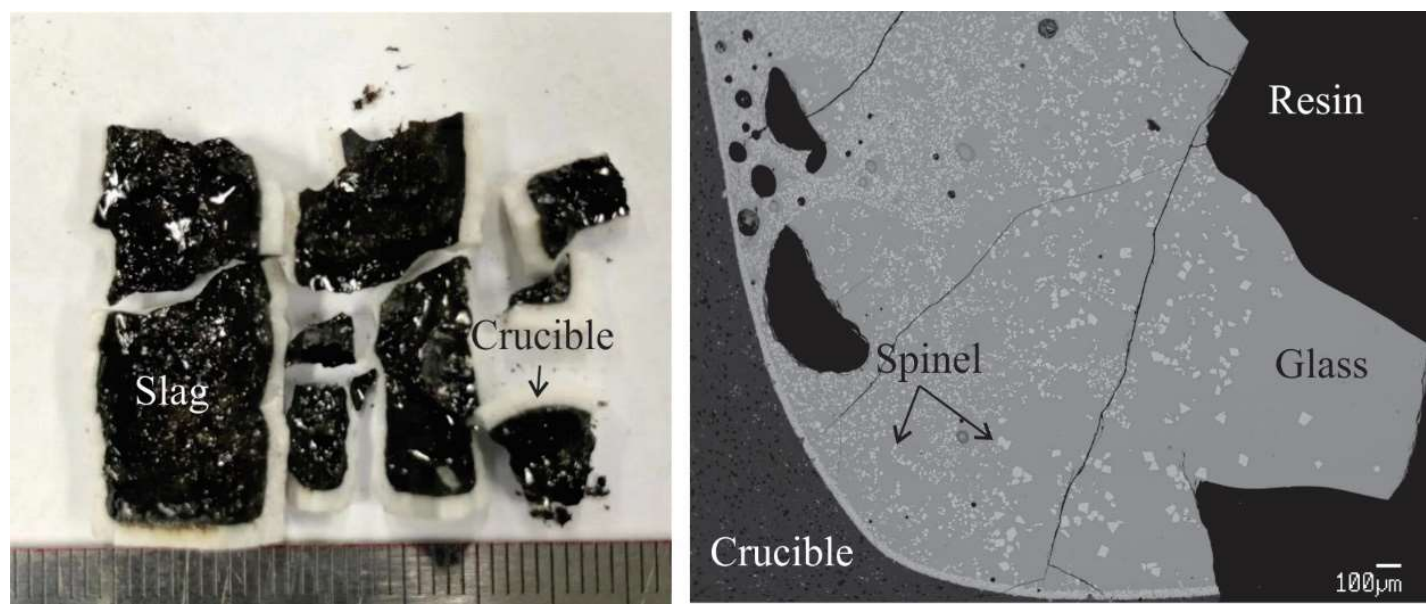

(a) Sample ND8 (2 wt\% graphite addition)
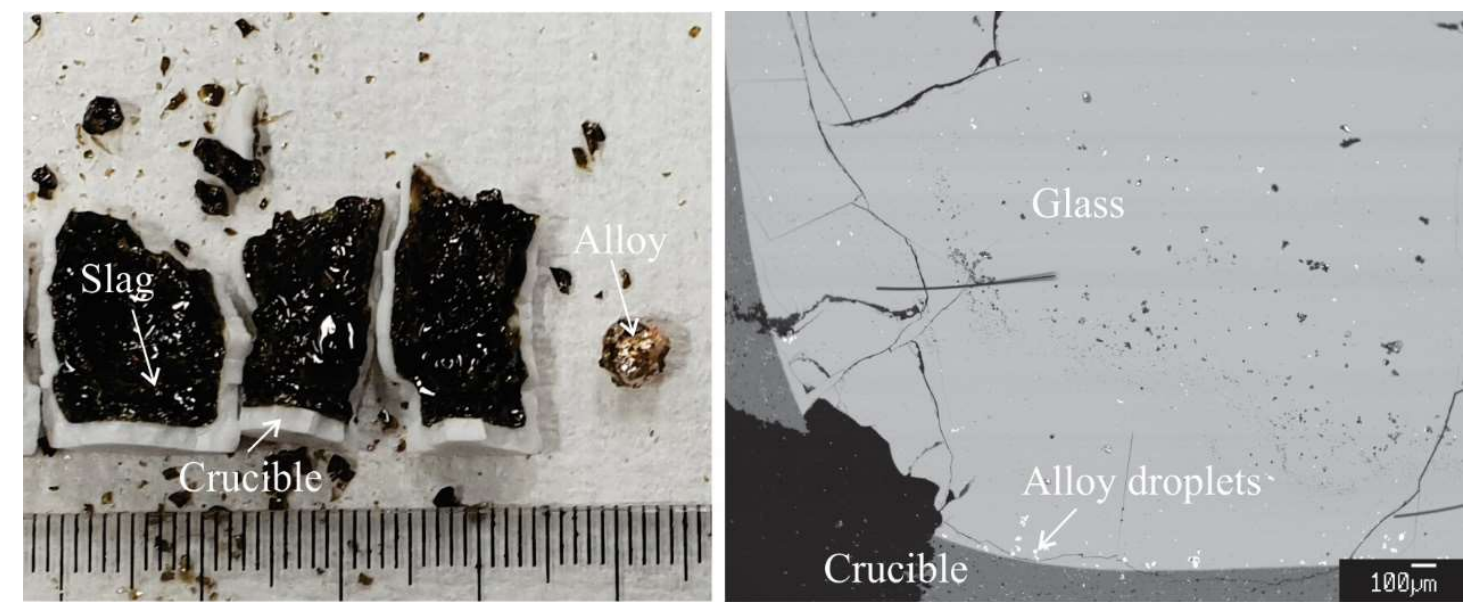

(b) Sample ND9 (4 wt\% graphite addition)

Figure 6. Cont. 

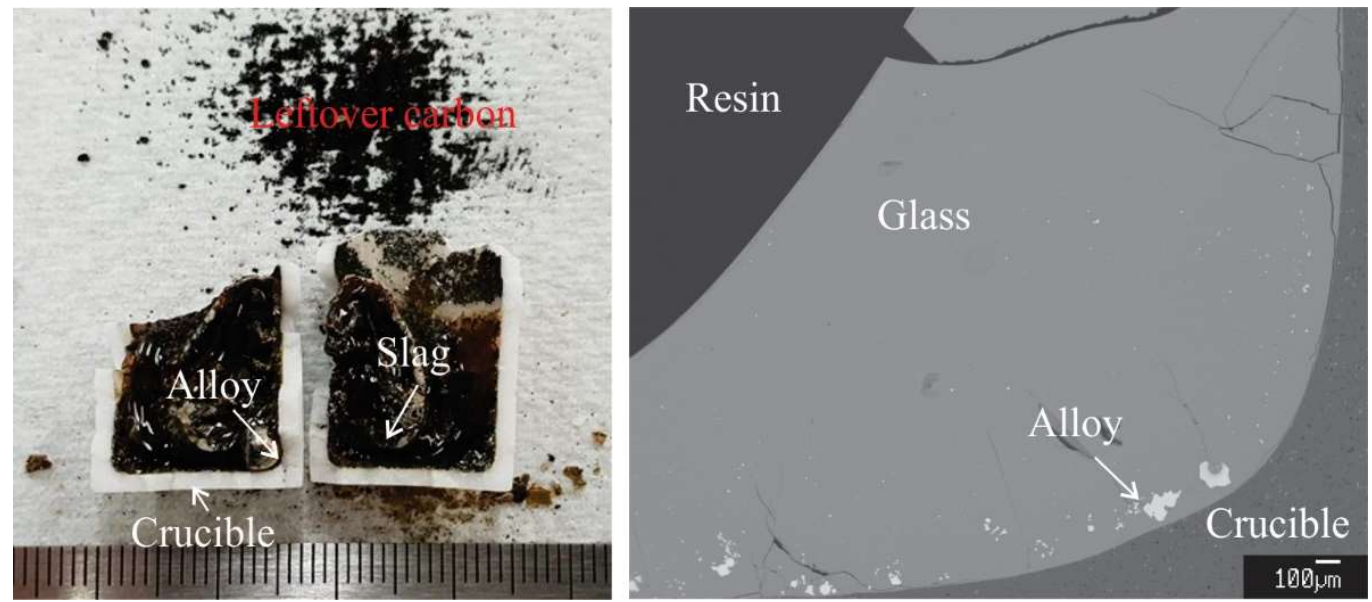

(c) Sample ND10 (6 wt\% graphite addition)

Figure 6. Pictures and microstructures of quenched samples after smelting at $1350{ }^{\circ} \mathrm{C}$. (a) Sample ND8 ( $2 \mathrm{wt} \%$ graphite addition); (b) sample ND9 (4 wt \% graphite addition); (c) sample ND10 (6 wt \% graphite addition).

\subsubsection{Effect of Flux Addition}

$\mathrm{SiO}_{2}$ as a flux was added to decrease the liquidus temperature of slag, which enables the slag to be a fully-liquid at the smelting temperature. FactSage calculations shown in Figure 3 demonstrated that the liquidus temperature of the slag decreases rapidly with the addition of up to $50 \mathrm{wt} \% \mathrm{SiO}_{2}$. Different amounts of $\mathrm{SiO}_{2}$ were added to verify the predictions at a given temperature of $1350{ }^{\circ} \mathrm{C}$. The dependence of $\mathrm{SiO}_{2}$ addition on the formation of slags with the same amount of graphite additive is shown in Figure 7. It is evident from Figure $7 \mathrm{a}-\mathrm{c}$ that the slags were fully liquid at the experimental temperature with $\mathrm{SiO}_{2}$ addition over $10 \mathrm{wt} \%$. However, as shown in Figure $7 \mathrm{~d}$, with the $\mathrm{SiO}_{2}$ addition down to $5 \mathrm{wt} \%$, the liquidus temperature of the slag was above the experimental temperature resulting in the presence of solid. The primary monoxide phase precipitated in the slag, and tiny reduced alloy blebs are distributed in the periphery of the monoxide solids. In addition to the liquidus temperature, the viscosity of slag can influence the settlement of alloys and tapping of slags. The viscosity of slags in the full-liquid state at $1350^{\circ} \mathrm{C}$ with the addition of different amounts of $\mathrm{SiO}_{2}$ was calculated by FactSage 7.2. Figure 8 shows the viscosity of slag increases with increasing $\mathrm{SiO}_{2}$. The addition of $\mathrm{SiO}_{2}$ needs to be minimized to keep the slags in a full liquid state with a relatively low viscosity. Overall, $\mathrm{SiO}_{2}$ addition can be optimized by several factors including the liquidus temperature of slag for operational temperature, the viscosity of slag for separation of alloy and slag tapping, and MnO-grade of the residue slag for further production of ferromanganese or silicomanganese alloys. 


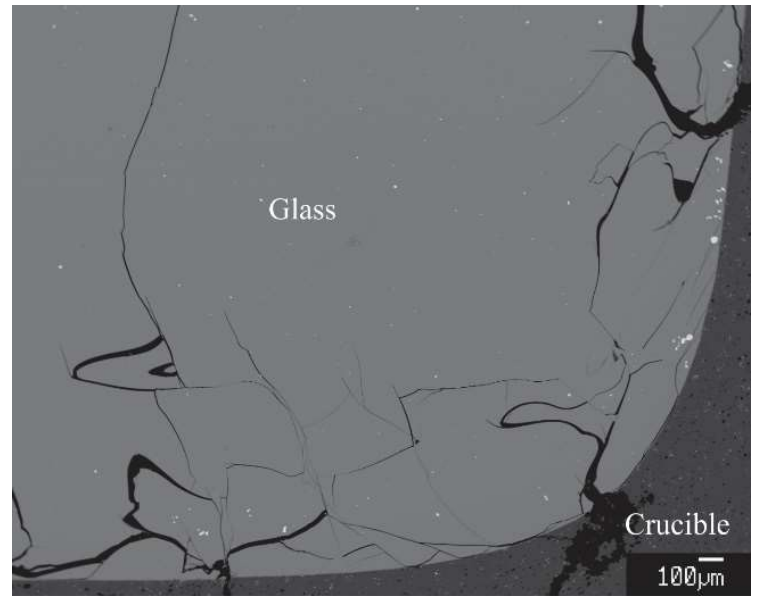

(a) Sample ND4 (adding $17.5 \mathrm{wt} \% \mathrm{SiO}_{2}$ )

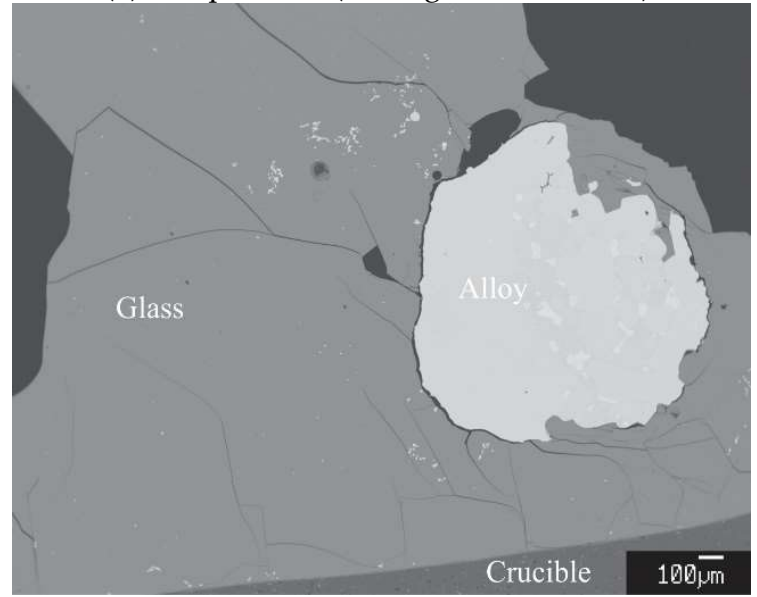

(c) Sample ND12 (adding $10 \mathrm{wt} \% \mathrm{SiO}_{2}$ )

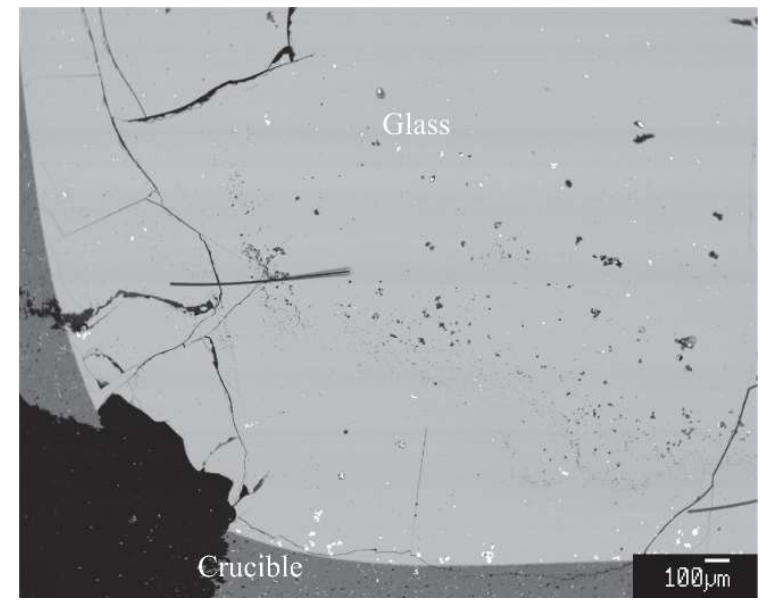

(b) Sample ND9 (adding $15 \mathrm{wt} \% \mathrm{SiO}_{2}$ )

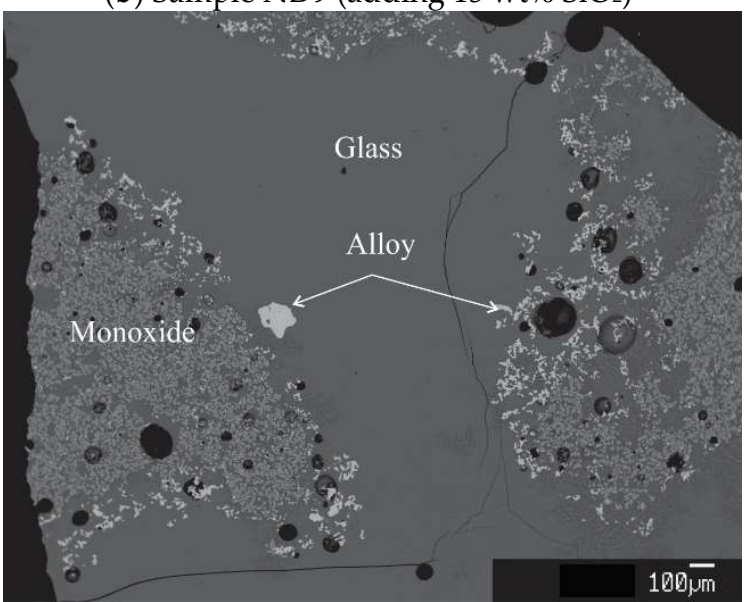

(d) Sample ND13 (adding $5 \mathrm{wt} \% \mathrm{SiO}_{2}$ )

Figure 7. Microstructures of slags of the quenched samples with different $\mathrm{SiO}_{2}$ addition.

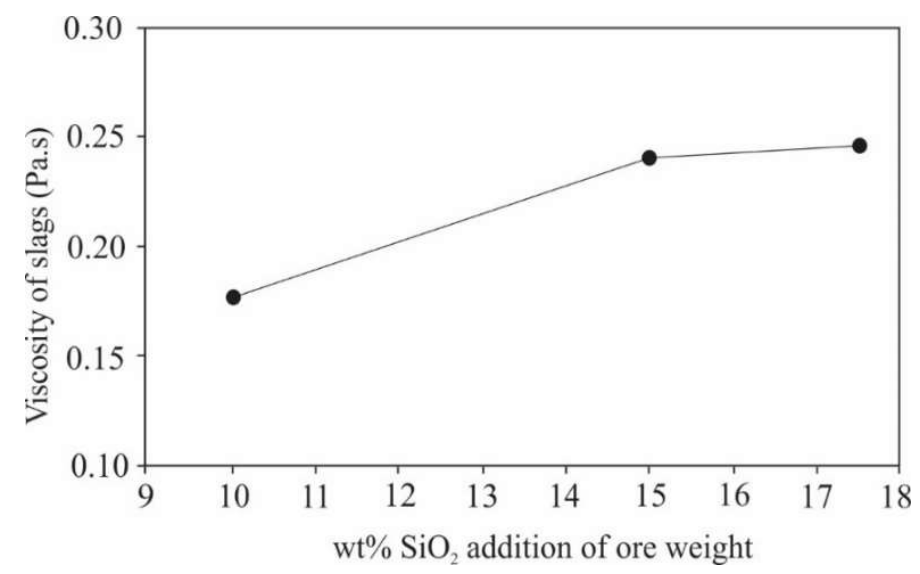

Figure 8. The viscosity of slags as a function of $\mathrm{SiO}_{2}$ addition ( $\mathrm{wt} \%$ ) of ore weight.

\subsection{Effect of Graphite Addition on the Alloy Grade}

The liquidus temperature of slags has been predicted by FactSage, and verified by the experiments with a variation of $\mathrm{SiO}_{2}$ flux and carbon addition in the above sections. The liquidus temperature of slags decreases with the $\mathrm{SiO}_{2}$ addition and reduction of $\mathrm{Fe}^{3+}$ to $\mathrm{Fe}^{2+}$ in the slag by carbon. The reduction degree of $\mathrm{FeO}$ in the slag and reduced Fe in the alloy as a function of carbon are shown in Figure 9, where experimental results of samples ND8 to $\mathrm{ND} 11$ with $15 \mathrm{wt} \% \mathrm{SiO}_{2}$ addition at $1350{ }^{\circ} \mathrm{C}$ are 
compared with FactSage calculation. The compositions of alloys and phases present in the quenched samples are listed in Table 4. Figure 9 shows FeO concentration in the slag decreases along with carbon addition, while Fe concentration in the alloy increases for experimental results. A significant difference was found between experimental results and FactSage calculation for the FeO reduction. FactSage calculation indicates $\mathrm{FeO}$ in the slag is fully reduced by $3 \mathrm{wt} \%$ carbon, while more carbon is needed in the experiments, in which approximately $8 \mathrm{wt} \%$ carbon can fully reduce the $\mathrm{FeO}$ in the slag. One of the reasons is that a small fraction of $\mathrm{MnO}$ was reduced during the carbothermic reduction, which resulted in carbon more than theoretical is needed. Moreover, the metallic oxides could present in multivalent forms (e.g., $\mathrm{MeO}_{\mathrm{x}}$ ) rather than bivalent form (e.g., $\mathrm{MeO}$ ) that require additional carbon to reduce them.

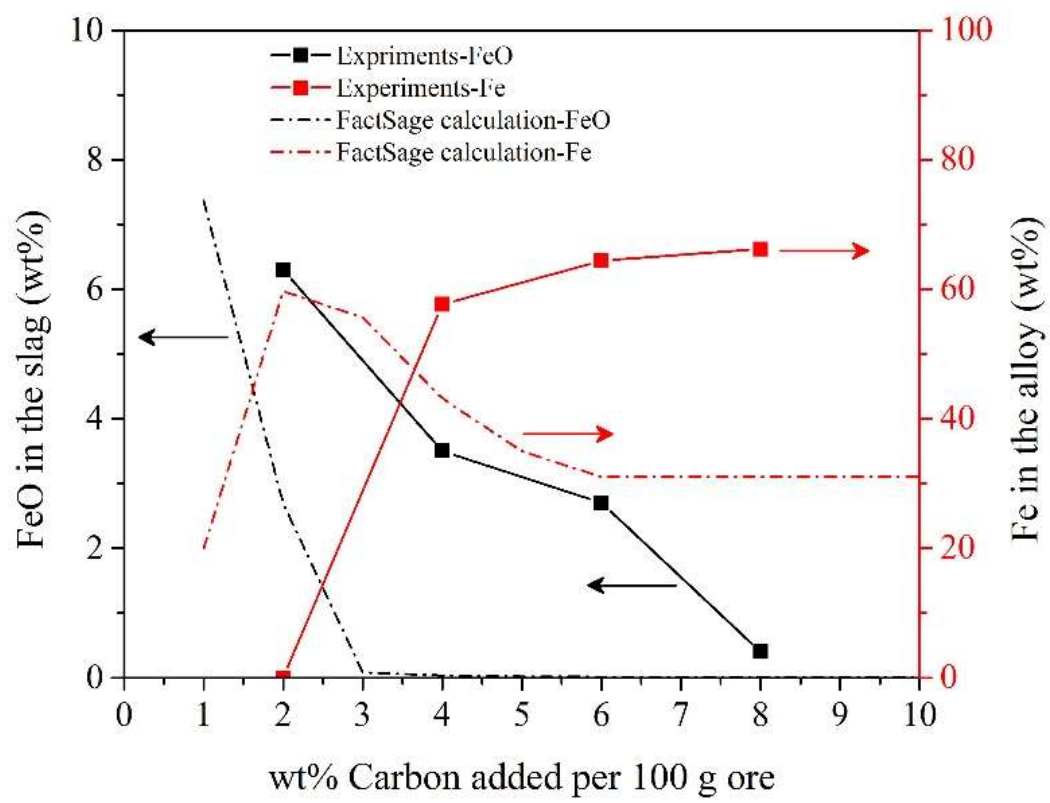

Figure 9. A comparison between experimental results and FactSage calculation on the FeO and Fe concentration in the slag and alloy with the addition of carbon.

Full reduction of $\mathrm{CuO}, \mathrm{NiO}$, and $\mathrm{CoO}$ are desired to allow for high recovery rates, while the iron oxide can be partly/sufficiently reduced depending on the amount of reductant. Recovery of $\mathrm{Cu}, \mathrm{Ni}$, and $\mathrm{Co}$ is taken as a whole, and the alloy grade is defined as the weight percentage of the sum of $\mathrm{Cu}$, $\mathrm{Ni}$, and $\mathrm{Co},(\mathrm{Cu}+\mathrm{Ni}+\mathrm{Co})$. The effect of graphite addition on the alloy grade is shown in Figure 10, where the data is plotted from Table 4 . The alloy grade decreases with increasing graphite addition. The sequential ease of reduction of metal oxides is $(\mathrm{Cu}, \mathrm{Ni}, \mathrm{Co})>\mathrm{Fe}>(\mathrm{Mn}, \mathrm{Si})$. The $(\mathrm{Cu}+\mathrm{Ni}+\mathrm{Co})$ concentration gradually decreases in the alloy along with the reduction of $\mathrm{Fe}$ and $\mathrm{Mn}$ oxides. Figure 10 can be divided into three areas, where "Area I" represents the insufficient addition of reductant and no alloys are reduced, "Area III" means excess addition of reductant, beyond that, $\mathrm{MnO}$ (or even $\mathrm{SiO}_{2}$ ) in the slag will be significantly reduced into the alloys. $\mathrm{SiO}_{2}$ and $\mathrm{MnO}$ are not required to be reduced at the smelting reduction stage to produce high-grade Fe-Ni-Cu-Co alloy. "Area II" in Figure 10 is thus the working area to optimize the addition of reductant to control the alloy grade and recovery of valuable metals. Within "Area II", iron oxide is gradually reduced into the alloy along with graphite additive. Iron oxide is almost fully reduced with $8 \mathrm{wt} \%$ graphite addition. 


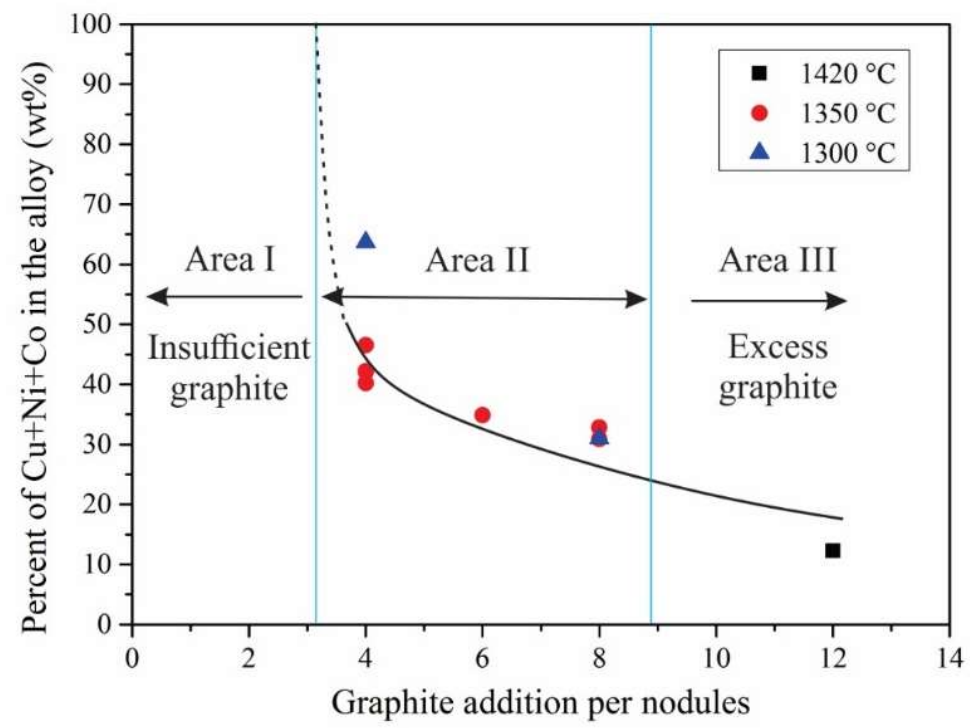

Figure 10. Relationship between alloy grade $(\mathrm{Cu}+\mathrm{Ni}+\mathrm{Co})$ and graphite addition.

Table 4. The compositions of the phases present in the quenched samples (wt \%).

\begin{tabular}{|c|c|c|c|c|c|c|c|c|c|c|c|c|c|}
\hline Sample No. & Slag & $\mathrm{MnO}$ & $\mathrm{SiO}_{2}$ & $\mathrm{Al}_{2} \mathrm{O}_{3}$ & "FeO" & $\mathrm{MgO}$ & $\mathrm{CaO}$ & $\mathrm{Na}_{2} \mathrm{O}$ & $\mathrm{K}_{2} \mathrm{O}$ & $\mathrm{TiO}_{2}$ & $\mathrm{Cu}_{2} \mathrm{O}$ & $\mathrm{NiO}$ & $\mathrm{CoO}$ \\
\hline \multirow{2}{*}{ ND1 } & Glass & 36.4 & 29.8 & 8.2 & 5.6 & 3.8 & 3.0 & 7.6 & 1.7 & 0.6 & 1.9 & 1.2 & 0.2 \\
\hline & Spinel & 62.2 & 0.5 & 8.2 & 19.7 & 3.3 & 0.1 & 0.0 & 0.0 & 0.8 & 0.7 & 4.1 & 0.4 \\
\hline \multirow[b]{2}{*}{ ND2 } & Glass & 36.0 & 30.4 & 9.4 & 4.4 & 3.7 & 3.1 & 7.9 & 1.6 & 0.5 & 1.9 & 0.8 & 0.2 \\
\hline & Spinel & 63.1 & 0.4 & 6.8 & 20.9 & 3.0 & 0.0 & 0.0 & 0.0 & 0.8 & 0.5 & 4.0 & 0.4 \\
\hline ND3 & Glass & 36.1 & 32.1 & 15.2 & 0.1 & 4.8 & 3.3 & 6.2 & 1.4 & 0.8 & 0.0 & 0.0 & 0.0 \\
\hline ND4 & Glass & 41.4 & 31.7 & 10.5 & 3.8 & 4.1 & 2.4 & 4.1 & 1.1 & 0.7 & 0.1 & 0.0 & 0.0 \\
\hline ND5 & Glass & 44.0 & 34.3 & 6.8 & 1.2 & 4.3 & 2.6 & 4.8 & 1.3 & 0.7 & 0.0 & 0.1 & 0.0 \\
\hline ND6 & Glass & 36.1 & 41.7 & 5.0 & 6.2 & 3.3 & 2.0 & 3.7 & 1.1 & 0.5 & 0.1 & 0.1 & 0.0 \\
\hline ND7 & Glass & 38.0 & 44.7 & 4.8 & 0.7 & 3.6 & 2.2 & 4.1 & 1.2 & 0.5 & 0.0 & 0.0 & 0.0 \\
\hline \multirow{2}{*}{ ND8 } & Glass & 40.3 & 32.2 & 6.3 & 6.3 & 3.9 & 2.5 & 3.1 & 1.7 & 0.5 & 1.4 & 1.5 & 0.3 \\
\hline & Spinel & 47.1 & 0.4 & 9.8 & 31.2 & 2.8 & 0.0 & 0.0 & 0.0 & 1.5 & 0.2 & 6.7 & 0.4 \\
\hline ND9 & Glass & 42.0 & 31.4 & 11.6 & 3.5 & 3.9 & 2.4 & 3.0 & 1.5 & 0.6 & 0.1 & 0.0 & 0.0 \\
\hline ND10 & Glass & 42.9 & 32.8 & 7.6 & 2.7 & 4.2 & 2.5 & 5.5 & 1.1 & 0.6 & 0.0 & 0.0 & 0.0 \\
\hline ND11 & Glass & 43.1 & 33.0 & 8.9 & 0.4 & 4.2 & 2.5 & 5.8 & 1.1 & 0.6 & 0.1 & 0.0 & 0.0 \\
\hline ND12 & Glass & 44.5 & 28.1 & 11.2 & 2.1 & 4.2 & 2.5 & 5.5 & 1.0 & 0.6 & 0.0 & 0.0 & 0.0 \\
\hline \multirow{2}{*}{ ND13 } & Glass & 47.1 & 22.9 & 10.5 & 3.4 & 4.2 & 2.8 & 6.7 & 1.1 & 0.7 & 0.0 & 0.0 & 0.0 \\
\hline & Monoxide & 86.5 & 0.0 & 0.3 & 6.8 & 5.9 & 0.1 & 0.1 & 0.0 & 0.1 & 0.1 & 0.1 & 0.1 \\
\hline Sample No. & Alloy & Mn & Si & Al & $\mathrm{Fe}$ & $\mathrm{Mg}$ & $\mathrm{Ca}$ & $\mathrm{Na}$ & K & $\mathrm{Ti}$ & $\mathrm{Cu}$ & $\mathrm{Ni}$ & Co \\
\hline ND3 & Alloy & 60.7 & 1.0 & 0.0 & 25.9 & 0.0 & 0.0 & 0.0 & 0.0 & 0.1 & 5.6 & 5.9 & 0.8 \\
\hline ND4 & Alloy & 0.3 & 0.0 & 0.0 & 53.2 & 0.0 & 0.0 & 0.0 & 0.0 & 0.0 & 20.2 & 23.1 & 3.2 \\
\hline ND5 & Alloy & 1.1 & 0.0 & 0.0 & 67.9 & 0.0 & 0.0 & 0.0 & 0.0 & 0.0 & 12.8 & 15.5 & 2.6 \\
\hline ND6 & Alloy & 0.1 & 0.0 & 0.0 & 36.1 & 0.0 & 0.0 & 0.0 & 0.0 & 0.0 & 24.8 & 34.5 & 4.4 \\
\hline ND7 & Alloy & 0.3 & 0.0 & 0.0 & 68.6 & 0.0 & 0.0 & 0.0 & 0.0 & 0.0 & 10.6 & 17.6 & 2.8 \\
\hline ND9 & Alloy & 0.2 & 0.0 & 0.0 & 57.7 & 0.0 & 0.0 & 0.0 & 0.0 & 0.0 & 18.3 & 20.7 & 3.1 \\
\hline ND10 & Alloy & 0.4 & 0.0 & 0.0 & 64.4 & 0.0 & 0.0 & 0.0 & 0.0 & 0.0 & 14.4 & 17.7 & 2.8 \\
\hline ND11 & Alloy & 0.9 & 0.0 & 0.0 & 66.2 & 0.0 & 0.0 & 0.0 & 0.0 & 0.0 & 13.8 & 16.5 & 2.5 \\
\hline ND12 & Alloy & 0.5 & 0.0 & 0.0 & 57.3 & 0.0 & 0.0 & 0.0 & 0.0 & 0.0 & 13.5 & 25.1 & 3.6 \\
\hline ND13 & Alloy & 0.5 & 0.0 & 0.0 & 59.2 & 0.0 & 0.0 & 0.0 & 0.0 & 0.0 & 25.1 & 12.6 & 2.5 \\
\hline
\end{tabular}

\section{Conclusions}

An efficient process for the smelting reduction of polymetallic nodules at a lower temperature was investigated by the optimization of both slag and alloy systems. Essential findings are summarized as follows: 
(1) The as-received nodules mainly contain Mn and Fe oxides in striation. Si is incorporated with $\mathrm{Al}, \mathrm{Na}, \mathrm{K}$ and $\mathrm{Ca}$ as impurity minerals. Valuable metal elements such as $\mathrm{Cu}, \mathrm{Co}$ and $\mathrm{Ni}$ in low concentrations are uniformly distributed in the nodule matrix. Ba is found to be associated with S, most likely as barite.

(2) FactSage software was used to simulate/predict the liquidus temperature of the slag system, which is not sensitive to $\mathrm{FeO}, \mathrm{CaO}$ and $\mathrm{Al}_{2} \mathrm{O}_{3}$, but decreases most significantly with decreasing $\mathrm{MnO} / \mathrm{SiO}_{2}$ mass ratio. The $\mathrm{SiO}_{2}$ flux to decrease the liquidus temperature of slag was experimentally verified.

(3) The alloy grade was found to decrease with increasing graphite addition. The optimal reduction was achieved by adding a $4 \mathrm{wt} \%$ graphite at the $\mathrm{MnO} / \mathrm{SiO}_{2}$ mass ratio of 1.6 in slag. The most effective metal-slag separation was achieved at $1350^{\circ} \mathrm{C}$. This relatively low-temperature smelting process for the utilization of polymetallic nodules is promising for industrial applications.

Author Contributions: Conceptualization, B.Z.; methodology, K.S.; formal analysis, X.M.; resources, J.P.;- original draft preparation, X.M.; writing-review and editing, K.S., B.Z. and J.P.; supervision, B.Z. All authors have read and agreed to the published version of the manuscript.

Funding: This research received no external funding

Acknowledgments: The authors would like to thank Jie Yu for the lab assistants in the high-temperature experiments. The authors acknowledge the facilities, and the scientific and technical assistance, of the Australian Microscopy and Microanalysis Research Facility at the Centre for Microscopy and Microanalysis, The University of Queensland. Tonga Offshore Mining Limited provided the sample of nodules tested.

Conflicts of Interest: The authors declare no conflict of interest.

\section{References}

1. Hein, J.R.; Mizell, K.; Koschinsky, A.; Conrad, T.A. Deep-ocean mineral deposits as a source of critical metals for high- and green-technology applications: Comparison with land-based resources. Ore Geol. Rev. 2013, 51, 1-14. [CrossRef]

2. Mittal, N.; Anand, S. Techno-economic Perspective on Processing of Polymetallic Ocean Nodules. In Environmental Issues of Deep-Sea Mining, 1st ed.; Sharma, R., Ed.; Springer: Cham, Switzerland, 2019; pp. 547-566.

3. Lipton, I.T.; Nimmo, M.J.; Parianos, J.M. Technical Report NI 43-101 TOML Clarion Clipperton Zone Project, Pacific Ocean; Nautilus Minerals Inc.: Toronto, ON, Canada, July 2016.

4. Mohwinkel, D.; Kleint, C.; Koschinsky, A. Phase associations and potential selective extraction methods for selected high-tech metals from ferromanganese nodules and crusts with siderophores. Appl. Geochem. 2014, 43, 13-21. [CrossRef]

5. Premchand, J.E.; Jana, R.K. Processing of polymetallic sea nodules: An overview. In Proceedings of the Third Ocean Mining Symposium, Goa, India, 8-10 November 1999; pp. 237-245.

6. Das, R.P.; Anand, S. Metallurgical Processing of Polymetallic Ocean Nodules. In Deep-Sea Mining, 1st ed.; Sharma, R., Ed.; Springer: Cham, Switzerland, 2017; pp. 365-394.

7. Sridhar, R.; Jones, W.E.; Warner, J.S. Extraction of copper, nickel and cobalt from sea nodules. JOM 1976, 28, 32-37. [CrossRef]

8. Sen, P.K. Metals and materials from deep sea nodules: An outlook for the future. Int. Mater. Rev. 2010, 55, 364-391. [CrossRef]

9. Acharya, S.; Das, R.P. Kinetics and Mechanism of the Reductive Ammonia Leaching of Ocean Nodules by Manganous Ion. Hydrometallurgy 1987, 19, 169-186. [CrossRef]

10. Anand, S.; Das, S.C.; Das, R.P.; Jena, P.K. Leaching of manganese nodule in ammoniacal medium using ferrous sulfate as the reductant. Metall. Trans. B 1988, 19, 331-334. [CrossRef]

11. Das, R.P.; Anand, S.; Das, S.C.; Jena, P.K. Leaching of manganese nodules in ammoniacal medium using glucose as reductant. Hydrometallurgy 1986, 16, 335-344. [CrossRef]

12. Jana, R.K.; Akerkar, D.D. Studies of the metal-ammonia-carbon dioxide-water system in extraction metallurgy of polymetallic sea nodules. Hydrometallurgy 1989, 22, 363-378. [CrossRef]

13. Jana, R.K.; Pandey, B.D.; Premchand, J.E. Ammoniacal leaching of roast reduced deep-sea manganese nodules. Hydrometallurgy 1999, 53, 45-56. [CrossRef] 
14. Mishra, D.; Srivastava, R.R.; Sahu, K.K.; Singh, T.B.; Jana, R.K. Leaching of roast-reduced manganese nodules in $\mathrm{NH}_{3}-\left(\mathrm{NH}_{4}\right)_{2} \mathrm{CO}_{3}$ medium. Hydrometallurgy 2011, 109, 215-220. [CrossRef]

15. Acharya, R.; Ghosh, M.K.; Anand, S.; Das, R.P. Leaching of metals from Indian Ocean nodules in $\mathrm{SO}_{2}-\mathrm{H}_{2} \mathrm{O}-\mathrm{H}_{2} \mathrm{SO}_{4}-\left(\mathrm{NH}_{4}\right)_{2} \mathrm{SO}_{4}$ medium. Hydrometallurgy 1999, 53, 169-175. [CrossRef]

16. Han, K.N.; Fuerstenau, D.W. Acid leaching of ocean manganese nodules at elevated temperatures. Int. J. Miner. Process. 1975, 2, 163-171. [CrossRef]

17. Anand, S.; Das, S.C.; Das, R.P.; Jena, P.K. Leaching of manganese nodules at elevated temperature and pressure in the presence of oxygen. Hydrometallurgy 1988, 20, 155-167. [CrossRef]

18. Parhi, P.K.; Park, K.H.; Nam, C.W.; Park, J.T.; Barik, S.P. Extraction of rare earth metals from deep sea nodule using $\mathrm{H}_{2} \mathrm{SO}_{4}$ solution. Int. J. Miner. Process. 2013, 119, 89-92. [CrossRef]

19. Kanungo, S.B.; Jena, P.K. Studies on the dissolution of metal values in manganese nodules of Indian Ocean origin in dilute hydrochloric acid. Hydrometallurgy 1988, 21, 23-39. [CrossRef]

20. Khalafalla, S.E.; Pahlman, J.E. Selective Extraction of Metals from Pacific Sea Nodules with Dissolved Sulfur Dioxide. JOM 1981, 33, 37-42. [CrossRef]

21. Senanayake, G. Acid leaching of metals from deep-sea manganese nodules-A critical review of fundamentals and applications. Miner. Eng. 2011, 24, 1379-1396. [CrossRef]

22. Sridhar, V.; Verma, J.K. Extraction of copper, nickel and cobalt from the leach liquor of manganese-bearing sea nodules using LIX 984N and ACORGA M5640. Miner. Eng. 2011, 24, 959-962. [CrossRef]

23. Zhu, Z.; Zhang, W.; Pranolo, Y.; Cheng, C.Y. Separation and recovery of copper, nickel, cobalt and zinc in chloride solutions by synergistic solvent extraction. Hydrometallurgy 2012, 127-128, 1-7. [CrossRef]

24. Monhemius, A.J. The extractive metallurgy of deep-sea manganese nodules. In Topics in Non-Ferrous Extractive Metallurgy, 1st ed.; Burkin, A.R., Ed.; Wiley: London, UK, 1980; pp. 42-49.

25. Agarwal, S.; Sahu, K.K.; Jana, R.K.; Mehrotra, S.P. Recovery of Cu, Ni, Co and Mn from Sea Nodules by Direct Reduction Smelting. In Proceedings of the 8th ISOPE Ocean Mining Symposium, Chennai, India, 20-24 September 2009; pp. 131-136.

26. Agarwal, A.; Sahu, K.K.; Godiwalla, K.M.; Rajak, D.K.; Smita, K.; Jana, R.K. An experimental and thermodynamic study on reduction smelting of sea nodules to recover valuable metals. In Proceedings of the XI International Seminar on Mineral Processing Technology, Jamshedpur, India, 15-17 December 2010; pp. 1024-1031.

27. Friedmann, D.; Friedrich, B. Optimized Slag Design for Maximum Metal Recovery during the Pyrometallurgical Processing of Polymetallic Deep-Sea Nodules. In Proceedings of the 10th International Conference on Molten Slags, Fluxes and Salts, Seattle, WA, USA, 22-25 May 2016; pp. 97-104.

28. Friedmann, D.; Friedrich, B.; Kuhn, T.; Ruhlemann, C. Optimized, zero waste pyrometallurgical processing of polymetallic nodules from the German CCZ license area. In Proceedings of the 46th Underwater Mining Conference, Berlin, Germany, 24-29 September 2017.

29. Friedmann, D.; Pophanken, A.K.; Friedrich, B. Pyrometallurgical Treatment of High Manganese Containing Deep Sea Nodules. J. Sustain. Metall. 2017, 3, 219-229. [CrossRef]

30. Sommerfeld, M.; Friedmann, D.; Kuhn, T.; Friedrich, B. "Zero-Waste": A Sustainable Approach on Pyrometallurgical Processing of Manganese Nodule Slags. Minerals 2018, 8, 544. [CrossRef]

31. Keskinkilic, E. Nickel Laterite Smelting Processes and Some Examples of Recent Possible Modifications to the Conventional Route. Metals 2019, 9, 974. [CrossRef]

32. Bale, C.W.; Bélisle, E.; Chartrand, P.; Decterov, S.A.; Eriksson, G.; Gheribi, A.E.; Hack, K.; Jung, I.-H.; Kang, Y.-B.; Melançon, J.; et al. FactSage thermochemical software and databases, 2010-2016. CALPHAD 2016, 54, 35-53. [CrossRef]

(C) 2020 by the authors. Licensee MDPI, Basel, Switzerland. This article is an open access article distributed under the terms and conditions of the Creative Commons Attribution (CC BY) license (http://creativecommons.org/licenses/by/4.0/). 